\title{
REDESIGNING SEMINARS IN THE SUBJECT SUSTAINABLE DEVELOPMENT AND ENVIRONMENTAL ETHICS FOR THE NEW ON- LINE HIGHER EDUCATION SCENARIO DUE TO COVID-19
}

\author{
N. Laguarda Miró, J. Ibáñez Civera, L. Gil Sánchez, E. García Breijo, J. Monreal \\ Trigo, J.M. Terrés Haro \\ Universitat Politècnica de València (SPAIN)
}

\begin{abstract}
Covid-19 has changed the global agenda this year 2020 and particularly since March when the disease disseminated and affected the whole world. Then, confinement strategies started in most of the countries affecting important humankind aspects such as economy, society, and many others. In an educational point of view, higher education has been suddenly forced to change from a traditional presential education structure to a non-presential learning-teaching framework based on virtual/on-line educational strategies.
\end{abstract}

Particular efforts have been done at the Universitat Politècnica de València (UPV) and in its Design Engineering School (ETSID) to adapt their educational model to this unexpected situation. This paper shows the work conducted to redesign seminars in the subject Sustainable Development and Environmental Ethics according to the requirements of this new scenario. A preliminary SWOT analysis allowed to focus our redesigning efforts in specific aspects of the seminar: assuming the nonpresential scenario and adapting to this new reality, an appropriate and more effective information sharing, some visual aspects associated to the specific teamworking dynamics in the classroom, structure and seminar schedule were some of the aspects to be on in the redesigning process. Students' opinions and point of view were particularly considered in redesigning as they are intensively experiencing on-line education since confinement started. Finally, structure, tasks, schedule, attendance, results compilation and sharing, and assessment were completely reconsidered and adapted.

After this season's experience, development, results and students' feedback have been studied in depth. As a conclusion, the new redesigned seminar rises as a successful improved version of the activity being more dynamic, participative, and educationally functional. Although, there are important aspects that have been lost because they are linked to presential attendance and real teamworking in the classroom. Further efforts will be focused in diminishing these disadvantages.

Keywords: Covid-19, distance learning, engineering, seminaries.

\section{INTRODUCTION}

The dissemination of COVID-19 all around the world has disrupted the global agenda this year 2020 . Particularly since March when the first confinements began in different countries including Spain [1]. From that moment on, aspects such as the economy, health, security, social relationships and, of course, education changed dramatically.

In an educational point of view, this confinement meant a sudden change in the way of teaching: from an education traditionally based on the students' attendance at class to another in which it was simply impossible. From one day to the next, a whole system for on-line education was implemented in which all the involved sectors took part (governments, educational centres and teachers as well as the students and their families from home) to achieve a certain success in this sudden change.

At the UPV, the confinement meant the cessation of any educational activity on the campuses and the introduction of a virtual learning-teaching modality by means of using computer tools such as video notes, the specific UPV for on-line education (Poliforma't) and Microsoft TEAMS for videoconferences and classes among others. It also involved the redesign of subjects, contents, specific teaching methodologies, practices and seminars, as well as the reconsideration of the exams given the evidence of not being able to take them in person in the classrooms. Summarizing, "lots of changes in a very short time [2]." 
The subject SUSTAINABLE DEVELOPMENT AND ENVIRONMENTAL ETHICS was easily adapted to this new scenario although changes were not minor since not only teaching methods were modified but also practices, seminars, exams and teamworking. Focusing on seminar $\mathrm{n}^{\circ} 1$, objectives, structure, tasks, calendar, type of attendance, communication tools and results compilation were adapted to the new reality. Fortunately, feedback from the students seems to show their satisfaction with this seminar and its educational results despite the changes that this new virtual education has provoked in the seminar and the fact that it is the first time this seminar is given on-line [3, 4].

\section{THE UPV FACING COVID-19}

The UPV's commitment to health, safety and welfare of both students and staff was evident from the beginning of the pandemics as any presential activity was cancelled since the very start of the state of alarm. Then, taking advantage of the spring holidays period in Valencia (Las Fallas), the UPV stablished a new on-line learning-teaching system based on the combined use of the own virtual learning platform (Poliforma't) and Microsoft TEAMS to carry out both classes and effective teacherstudent communications. The semester was successfully concluded conducting all the examinations throughout the virtual platform Poliforma't.

As summer arrived and the confinement measures relaxed in Spain, the UPV scheduled next course to start in September in a normal scenario but considering a possible "B" scenario of physical "semiattendance" of the students in the classes just in case a second wave of the virus appeared. As it finally happened, the UPV was forced to establish the "B" scenario in which education is taking place nowadays. This intermediate scenario consists of virtual classes via on-line except a) the first courses of all our Degrees, b) fundamental practices that can only be conducted with the personal assistance of the student to the laboratory and c) exams.

\section{SUSTAINABLE DEVELOMPENT AND ENVIRONMENTAL ETHICS}

As described in preliminary papers [5, 6], SUSTAINABLE DEVELOPMENT AND ENVIRONMENTAL ETHICS is a 4,5 ECTS eligible subject included in the program of all the Engineering Degrees given in the ETSID. Its main goal is to be a window to nature and the environment for the students to know about them and also sensitize them to consider the environmental aspect in their decision making both as individuals and as future engineers.

One of its main particularities is that SUSTAINABLE DEVELOPMENT AND ENVIRONMENTAL ETHICS is based on the active role of the students at class and, thus, active methodologies such as flip teaching and teamworking are used. Consequently, a continuous assessment method is used to evaluate the students' evolution in the subject. More aspects about contents, structure, educational methods and assessment can be found in the course description [3].

\section{THE SEMINAR “THE LITTLE UN"}

The first seminar of the subject is called "The little UN" as it simulates an ordinary session of the United Nations Organization. The seminar is conceived as a teamworking activity to be carried out when a third of the contents have been already given and there is enough confidence among the students and a well stablished participative dynamic at class. The objective of this seminar is double: in the one hand, let the students know how an ordinary United Nations meeting is conducted and let them develop strategies to debate and participate in an appropriate way in this kind of events, and in the other hand, let them realize about how difficult is to identify complex environmental problems, their causes and consequences and find solutions from the leader global organizations. This seminar is being conducted every year since 2003 and results encourage the authors to keep on developing it disseminating the experience year after year [7].

\subsection{The seminar until today}

Until now, the seminar had been a teamworking activity to be developed jointly in the classroom. The seminar was structured in three different stages:

- Stage 1. The beginning of the session. The students receive an envelope containing all the information regarding a country. Envelopes were randomly distributed. Once the info has been 
read, the students must contact among them depending on the countries they are representing in order to prepare strategies for the further debate.

- Stage 2. The teacher reads a communication from the general secretariat of the United Nations asking for a meeting to solve a problem. Thus, the debate starts and the countries must define the problem, identify their causes and consequences. Next, they must work altogether to find solutions to the problem.

- Stage 3. The member states of the UN must write a synthesis document (statement) describing the problem, causes and consequences and, obviously, the accorded solutions to solve it.

\subsection{Redesigning the seminar}

Given the described scenario, the seminary had to be redesigned to adapt it to the new educational context. To do so, a preliminary study of the seminar particularities till the day was carried out. This allowed to be conscious of the strengths and weaknesses of the seminar in order to face the new online version. Some of the most remarkable aspects found in this study were the following:

Table 1. SWOT analysis of the seminar.

\begin{tabular}{|l|l|}
\hline \multicolumn{1}{|c|}{ Strenghts } & \multicolumn{1}{|c|}{ Weaknesses } \\
\hline \hline Physical attendance at class & Effort, time and dedication needed \\
Direct contact among students & Students have to organize themselves \\
$\begin{array}{l}\text { Active role of the students al class } \\
\text { Teacher is a mere tutor but not interfering into de } \\
\text { development of the activity }\end{array}$ & \\
$\begin{array}{l}\text { Teamworking } \\
\text { Dynamic Structure }\end{array}$ & \\
Role game & \\
Visual elements are very effective & \\
\hline \hline \multicolumn{1}{|c|}{ Opportunities } & \\
\hline \hline This seminar is always on & There is a threat of demotivation if students do not \\
Students give positive feedback year after year & Connect to the activity \\
\hline \hline
\end{tabular}

As a result of this analysis, authors concluded that there were some aspects of the seminar that should be modified for the new on-line edition. The most relevant were the following:

\subsubsection{Assume the virtual edition of the seminar as soon as possible and be used to it}

This was the basic conceptual pillar that had to be changed. It is useless not to assume reality. It was therefore necessary to assume that the seminar, as well as the rest of the subject, would be given virtually, in a remote manner. Thus, from that change in mentality, fundamental aspects of the seminar could begin to change.

\subsubsection{Information processing}

The information, which used to be given in the classroom itself and which was intentionally meager to avoid conditioning the students in the development of their creativity throughout the Seminar, has radically changed.

First, all the information from the seminar was reviewed, updated and restructured so that it was easily communicable to students and understandable at first reading. To do this, everything was prepared in three clear documents that were provided to the students one week in advance: 1. Instructions, 2. Official UN Communiqué and 3. List of the represented countries.

Given the new teacher-student communication platforms developed because of the virtual education scenario due to the pandemic, teachers decided to use all of them to bring the instructions and the information to the students. Thus, 1. An announcement in Poliforma't was conducted, 2. An email was 
written and 3. An announcement and a note in the schedule were added into the subject's channel in TEAMS.

With all these premises, information was assured to reach to the students in a clear and understandable way, reminding the date of the seminar in the calendar and saving all the information in one or more repositories for subsequent asynchronous reproduction of the session.

\subsubsection{Visual aspects}

All the labels and cards that were usually used in the seminar to clearly identify the countries' representatives were discarded for online use as they no longer made sense. As students were not altogether in the same physical space, the paper and paperboard labels with the names of the countries had to be replaced.

The alternative proposal was original and visual: tell the students to change the old labels for the flag of the country that they represented in the form of an avatar. This achieved a much more visual and dynamic effect in the on-line session of the seminar as it strongly clarified the identification of the students who were speaking.

\subsubsection{Structure}

The structural basis of the seminar itself had to be changed. In the traditional structure, sessions were quite open, flexible and adaptative to the evolution of the seminar at class but always following a basic guide: 1. Explanation and distribution of the information. 2. Conduct a preliminary individual work to prepare the seminar and 3. Development of the debate by means a review of the instructions, the debate itself simulating a session of the UN, and identifying causes and consequences of the problem to be sold to finish with 4 . Writing a report (statement) synthetizing the problem and the accorded solutions.

Thus, the new structure of the seminar was based in the traditional idea of flip teaching to be the following:

1 Delivery of all the information to the students to prepare the seminar in advance. The distribution of the information was carried out one week before the date of the seminar.

2 Monitoring the preliminary individual work of the students at home by tutorial given in TEAMS all along the previous week to the seminar. Also, promotion of bilateral or multilateral summits to prepare the session.

3 In the date of the seminar, hold the UN session directly without any preliminary work in the classroom as int has already been done at home. Along the session, give the floor to the General Secretary of the UN and then to the representatives of the countries by request. With these participations it is intended to identify the problem, causes and consequences and finally, the search for feasible proposals to solve it.

4 Conclusions, report (declaration), and end of the seminar.

\subsubsection{Development of the seminar}

Obviously, the development of the seminar itself was affected by the circumstances. The activity continued to be carried out as teamworking but the virtual scenario dramatically limited direct contact among the students. Thus, there were two fundamental aspects that were reconsidered:

a) The involvement of the teacher in the development of the session. In this case, it we much more invasive in order to compensate the shortcomings due to the on-line scenario.

b) Early facilitation of the information to the students so that the preliminary work at home was better and deeper both individually and in group. The fact that the students knew their corresponding countries in advance was a motivating factor.

In addition, given the limitations of teamworking in on-line sessions, an attempt to restrict the seminar was made. The idea was to control the spontaneous participation of the students in order to avoid the students to trample one to another when speaking or the topic of the seminar to be diverted. This control also should assure the accomplishment of the "tempos" and the development of each stage of the seminar in the pre-stablished time to appropriately lead the activity to its results and conclusions.

The main goal was to carry out the virtual version of the seminar without diminishing the relevance of the active role of the students in the activity. 


\subsection{Results \& Feedback}

The seminar has turned out to be a very remarkable activity in terms of participation. Despite the assistance was not mandatory and it was conducted on-line, attendance reached 74/84 students representing $88,10 \%$. This percentage in on the average of the previous editions of this seminar conducted in face-to-face conditions as seen in the table below:

Table 2. Participants vs total students in the subject.

\begin{tabular}{lccccc}
\hline \hline \multicolumn{1}{c}{ Year } & 2016 & 2017 & 2018 & 2019 & 2020 \\
\hline Participants & 61 & 49 & 55 & 72 & $\mathbf{7 4}$ \\
\hline Total & 69 & 56 & 61 & 76 & $\mathbf{8 4}$ \\
\hline Percentage & $88.4 \%$ & $87.51 \%$ & $90.16 \%$ & $91.13 \%$ & $\mathbf{8 8 . 1 0 \%}$ \\
\hline \hline
\end{tabular}

On the other hand, the result of the activity has been very positive since the educational goals have been achieved and particularly those referring to the development of the transversal competences such as: criticism, effective verbal communication, and social, ethical and environmental responsibility [6].

In addition, the received feedback from the students has also been very positive and enrichening as it has been the first one in a virtual scenario. Thus, some of the most outstanding comments from the students have been:

Table 2. Feedback from the students.

\begin{tabular}{|c|c|}
\hline Positive aspects of the seminar & Aspects to be improved \\
\hline $\begin{array}{l}\text { It is a very interesting seminar } \\
\text { Motivating }\end{array}$ & $\begin{array}{l}\text { One-minute speech per country } \\
\text { would have allowed all students to } \\
\text { work equally. }\end{array}$ \\
\hline $\begin{array}{l}\text { Funny and dynamic } \\
\text { On-line teaching in this way is very useful, dynamic and respectful when } \\
\text { students are speaking }\end{array}$ & \multirow[t]{2}{*}{$\begin{array}{l}\text { On-line teaching allows some } \\
\text { students to "disappear" and not } \\
\text { participate. Consequently, the activity } \\
\text { is not as brilliant as it should. }\end{array}$} \\
\hline Preliminary work is fundamental to carry out the seminar & \\
\hline $\begin{array}{l}\text { Useful to sensitize people about the environmental landscape in the } \\
\text { world. } \\
\text { It is a crude look at the global reality }\end{array}$ & $\begin{array}{l}\text { A little disorganization in the } \\
\text { interventions of the students }\end{array}$ \\
\hline $\begin{array}{l}\text { It can be seen how difficult is to reach to agreements among the } \\
\text { countries in the UN }\end{array}$ & $\begin{array}{l}\text { In person it would have been even } \\
\text { more dynamic! }\end{array}$ \\
\hline Surprising on-line work via TEAMS & The virtual scenario is a bit dull \\
\hline Success as one realizes it is working on & This activity needs more time! \\
\hline $\begin{array}{l}\text { It is useful to get on the fact that decreasing ecological footprint is on us. } \\
\text { Interesting simulation of a United Nations session. }\end{array}$ & \multirow[t]{8}{*}{ What a pity it was not in person.... } \\
\hline $\begin{array}{l}\text { The seminar let us open our eyes to the behavior of the nations } \\
\text { regarding the environment. }\end{array}$ & \\
\hline $\begin{array}{l}\text { It is like traveling to the country that I have represented, I have studied it } \\
\text { so much! }\end{array}$ & \\
\hline Each country looks for itself! & \\
\hline Social mobilization is very important & \\
\hline It allows knowing how difficult it is to reach agreements & \\
\hline The previous multilateral meetings have been very productive & \\
\hline $\begin{array}{l}\text { It favors the acquisition of transversal competences such as critical } \\
\text { thinking, effective verbal communication and, social, ethical, and } \\
\text { environmental commitment }\end{array}$ & \\
\hline
\end{tabular}




\section{CONCLUSIONS}

Covid 19 has changed many things this 2020 and also Higher Education that is nowadays conducted in an online scenario. It has led to a rapid adaptation of Universities to a new reality that has been reasonable to be assumed by this subject. Its particularities have helped to this adaptation.

Seminar $n^{0} 1$ of the subject has been successfully modified and adapted due to a SWOT analysis that has allowed to identify strengths, weaknesses, opportunities, and assume them in the adaptation process. This update consists of modifying a) the way this seminar is conducted, b) visual elements, c) structure and d) development of the seminar.

Both, the obtained results and the feedback from students allow us to consider the on-line edition of the seminar a successful experience in terms of participation, development and achievement of the educational goals. Thus, the experience encourages us to advance in its implementation and continue with the labour of improving it by the day.

\section{ACKNOWLEDGEMENTS}

Special thanks must be given to the student body of the subject Sustainable Development and Environmental Ethics in the course 2020/2021. Their compromise, hard work and active participation allowed this initiative to become true.

\section{REFERENCES}

[1] Gobierno de España. "Real Decreto 463/2020, de 14 de marzo, por el que se declara el estado de alarma para la gestión de la situación de crisis sanitaria ocasionada por el COVID-19." BOE, 67, March, 2020, https://www.boe.es/eli/es/rd/2020/03/14/463/con

[2] UPV. "instrucción del vicerrectorado de estudios, calidad y acreditación de la Universitat Politècnica de València, sobre medidas extraordinarias en coordinación con el vicerrectorado de alumnado, cultura y deporte y el vicerrectorado recursos digitales y documentación, para organizar la docencia y aprendizaje a distancia frente a la suspensión de la docencia presencial por causa de la epidemia del virus covid-19", Valencia: Vicerrectorado de Estudios, Calidad y Acreditación (UPV), 2020. http://www.upv.es/noticias-upv/documentos/11933-recomendacionesdocenciaadistanciaUPV.pdf

[3] UPV. "Course Description: Sustainable Development and Environmental Ethics", Universitat Politècnica de València, 2020, file:///C:/Users/nilam/Downloads/GD_E_13662_2020_C_163_ 20200713221338\%20(1).pdf

[4] UPV. "Annex to the Course Description: Sustainable Development and Environmental Ethics", Universitat Politècnica de València, 2020, file:///C:/Users/nilam/Downloads/AX_E_13662_2020_ C_163_20200909083827\%20(1).pdf

[5] N. Laguarda-Miro et al., "From "sustainable development and environmental ethics" to "environmental technology". Adapting sensitization subjects to the new degrees," in Proceedings of the 8th International Technology, Education and Development Conference (INTED), 41964202, Valencia: IATED, 2014.

[6] N. Laguarda-Miro et al., Assessing transversal competences in sustainable development and environmental ethics. Environmental sensitization under review, 10th International Technology, Education and Development Conference (INTED), 8347-8352, Valencia: IATED, 2016.

[7] N. Laguarda-Miro et al., transferring learning methodologies. The case of active role playing experiences in sciences higher education in UNIJUI (Brazil), 5th International Technology, Education and Development Conference (INTED), 4381-4385, Valencia: IATED, 2016. 